\title{
Association of Serum Vitamin D with Acute Myocardial Infarction in Young Patients ( $\leq 40$ Years)
}

\author{
ABM Imam Hosen ${ }^{1}$, Abdul Wadud Chowdhury², Khondker Md. Nurus Sabah ${ }^{3}$, Mohammad GaffarAmin ${ }^{4}$, \\ Mohsin Ahmed ${ }^{5}$, Azizul Haque ${ }^{6}$, Mohammed Nizam Uddin ${ }^{6}$, Biswanath Sarker ${ }^{7}$, Khandaker Abu Rubaiyat ${ }^{7}$, \\ Md. Noor-E-Khuda ${ }^{1}$. Md. Mesbahul Islam ${ }^{7}$
}

\begin{abstract}
:
Background: Coronary heart disease (CHD) is the leading cause of death worldwide, with acute myocardial infarction (AMI) being the most severe manifestation. Recent evidence suggests that vitamin D deficiency (moderate/severe) is an important risk factor for coronary artery disease. Objectives: Considering paucity of the literature focusing young MI, the study was planned to assess the relation of different grades of low serum vitamin D with AMI in young patients admitted in a tertiary care hospital. Methods: This Hospital based case-control study was conducted in the department of cardiology in Dhaka Medical College Hospital (DMCH) over 1 -year period. Patients with acute $\mathrm{MI}$ in young age ( $\leq 40$ years) admitted in the CCU of DMCH were approached for inclusion in the study. Total 120 subjects (60 cases and 60 controls) were studied. Patients with acute MI were considered as cases and similar number of age and sex matched apparently healthy individual were included as controls. All study population were subjected to relevant investigations and detailed history along with socio-demographic data were collected. Serum vitamin D levels were categorized as severe vitamin $D$ deficiency as a level $<10 \mathrm{ng} / \mathrm{ml}$, moderate vitamin $D$ deficiency at a level $10-20 \mathrm{ng} / \mathrm{ml}$, vitamin $D$ insufficiency as $21-29 \mathrm{ng} / \mathrm{ml}$ and a level of $\geq 30 \mathrm{ng} / \mathrm{ml}$ was
\end{abstract}

considered as normal. Serum $25(\mathrm{OH})$ vitamin $\mathrm{D}$ assay was performed for cases and controls using chemiluminescence immunoassay. Vitamin D status (normal/insufficiency vs moderate/severe deficiency) was studied among cases and controls. All necessary information were recorded in a pretested case record form. Statistical analyses were done by SPSS 22. Results: Mean age of cases and controls were $35.31 \pm 4.84$ and $33.83 \pm 5.11$ years respectively. Vitamin $D$ deficiency (moderate/severe) was present in $86.7 \%$ cases and $46.7 \%$ controls and the difference was statistically significant $(\mathrm{P}<0.001)$. Among 60 cases of acute MI, 83\% patients had acute ST segment elevated myocardial infarction and $17 \%$ patients had acute non-ST segment elevated myocardial infarction. Vitamin D deficient (moderate/severe) subjects were more likely to develop AMI than subjects who had normal/insufficient vitamin D levels in blood (OR 7.42, $95 \% \mathrm{Cl} 3.18-18.28, \mathrm{P}<0.001)$. And among all the usual coronary risk factors, vitamin $\mathrm{D}$ deficiency (moderate/ severe), Hypertension, Family history of premature CAD and smoking were significantly associated with increased incidence of acute MI (STEMI and NSTEMI) (P value $<0.05$ in all cases). Conclusion: Vitamin $D$ deficiency (moderate/severe) is associated with increased incidence of acute $\mathrm{MI}$ in young age ( $\leq 40$ years).

Keywords: Vitamin D; Myocardial infarction young

1. Medical Officer, Deputed Dhaka Medical College, Dhaka, Bangladesh.

2. Prof. and Head, Department of Cardiology, Dhaka Medical College, Dhaka, Bangladesh.

3. Associate Professor, Department of Cardiology, Mugda Medical College, Dhaka, Bangladesh.

4. Assistant Professor, Department of Cardiology, Dhaka Medical College, Dhaka, Bangladesh.

5. Associate Professor, National Institute of Cardiovascular Disease, Dhaka, Bangladesh.

6. Registrar, Department of Cardiology, Dhaka Medical College, Dhaka, Bangladesh

7. Registrar-Cardiology, IbnSina Specialized Hospital Dhanmondi, Dhaka, Bangladesh.

Address of Correspondents: A.B.M Imam Hosen, MBBS, BCS, MD(Cardiology), Medical Officer, Dhaka Medical College \& Hospital Mobile: 01914857767, Email: imamhosen.m38@gmail.com

DOI: https://doi.org/10.3329/bhj.v34i2.44437

Copyright $\odot 2017$ Bangladesh Cardiac Society. Published by Bangladesh Cardiac Society. This is an Open Access articles published under the Creative Commons Attribution-NonCommercial 4.0 International License (CC BY-NC). This license permits use, distribution and reproduction in any medium, provided the original work is properly cited and is not used for commercial purposes. 


\section{Introduction:}

Acute coronary syndrome is one of the leading causes of premature death in men and women despite unquestionable progress in the management and prevention of coronary artery disease. ${ }^{1}$.

Hypovitaminosis D or low serum vitamin D is highly prevalent in the United States and worldwide. It has been estimated that around 1 billion people worldwide suffer from low serum vitamin D.2 Although a consensus regarding the optimal level of serum $25(\mathrm{OH}) \mathrm{D}$ has not been established, most experts define severe vitamin $D$ deficiency as a level $<10 \mathrm{ng} / \mathrm{ml}$, moderate vitamin $D$ deficiency as a level $10-20 \mathrm{ng} / \mathrm{ml}$, vitamin $D$ insufficiency as $21-29 \mathrm{ng} / \mathrm{ml}$ and a level of $\mathrm{e}^{\prime \prime} 30 \mathrm{ng} / \mathrm{ml}$ is considered as normal. ${ }^{3}$ There is high prevalence of hypovitaminosis D among Indians despite the availability of abundant sunshine in large parts of India. This is true for both urban and rural populations and, in men and women, with reported population of prevalence of $70-99 \%$, with severe deficiency $(<10 \mathrm{ng} / \mathrm{ml}$ ) being reported as $62 \%$ in studies from Delhi. ${ }^{4-7}$ Another review of vitamin D deficiency in Bangladesh showed prevalence of hypovitaminosis D in Dhaka among $16-40$ years women being $12-17 \%$ and in Nandail $38-50 \% .^{5}$

Several mechanisms, direct and indirect, have been proposed for the association of vitamin D with CHD. Vitamin $D$ could be related to CHD via increased blood pressure, impaired glycemic control or secondary hyperparathyroidism. An excess of PTH levels is known to promote atherosclerosis. PTH promotes myocyte hypertrophy and vascular remodeling. Hypovitaminosis $D$ is known to up-regulate Renin Angiotensin Aldosterone System (RAAS) and lead to hypertrophy of smooth muscles and left ventricle, an adverse marker of cardiovascular event. ${ }^{8}$ Consequently, low serum $25(\mathrm{OH})$ $\mathrm{D}$ has been associated with aberrant cardiac contractility, cardiomegaly, and increased ventricular mass due to myocardial collagen deposition. ${ }^{9-10}$ Low serum Vitamin $D$ also leads to endothelial dysfunction by creating a proinflammatory and prothrombotic environment. This promotes atheroma formation and atherosclerosis, the principal cause of myocardial infarction (MI). ${ }^{11}$

Association of hypovitaminosis D with coronary heart disease (CHD) has been reported in a large number of studies and reviews recently. ${ }^{2,} 12-14$ There is also evidence of linking low serum vitamin $D$ to early mortality, with vitamin $D$ being considered as one of the possible treatable cardiovascular risk factors. ${ }^{2,15-16}$

However, there is no data on the association of low serum vitamin $D$ with $A M I$ in young ( $\leq 40$ years) Bangladeshi population. We therefore studied the association of this novel and potentially treatable risk factor of acute $\mathrm{Ml}$ in our population. We analyzed fasting serum vitamin D level in cases of newly diagnosed young acute myocardial infarction (MI) patients and age and sex matched controls, to study the association of low serum vitamin D with AMI in Bangladeshi population.

\section{Methods:}

This case - control study was conducted at the Department of Cardiology, Dhaka Medical College Hospital, Dhaka, between May'2017 to April'2018. Serum 25-hydroxy [25(OH)] vitamin D measurement was performed at blood sample collected and then stored at $-70^{\circ} \mathrm{C}$ in the biochemistry laboratory of BSMMU.

Newly diagnosed Patients with acute MI(STEMI and NSTEMI) in young age ( $\leq 40$ years) admitted in the CCU of Dhaka Medical College Hospital, Dhaka, within the study period who fulfilled the other inclusion and exclusion criteria were taken as cases and age and sex matched healthy subjects with no history of Ischemic heart disease (IHD) and normal ECG were taken as controls. Study subjects having previous history of myocardial infarction/Unstable angina /Percutaneous Coronary Intervention (PCI)/Coronary Artery Bypass Graft (CABG) were excluded. Controls were matched to cases by age and sex with healthy subjects (doctors, medical students, nurses, other hospital staffs and patients attendants from DMCH, Dhaka) with no history of IHD and normal ECG findings. Cases and controls with cardiomyopathy, any valvular heart disease, congenital heart disease, pericardial disease, pregnancy, known liver, thyroid, renal diseases, malabsorption or malignancy, and those who were taking vitamin D supplement were excluded.CHD in the young is defined as CHD in patients ( $\leq 40$ years) of age. The sample size for this study was calculated for a two sided significance of 0.05 and study power of $90 \%$. The calculated sample size was 60 cases and 60 controls. Serum vitamin D was measured in both cases and controls by chemiluminescence immunoassay on blood samples collected and then stored at $-70 p \mathrm{c}$ in the biochemistry laboratory of BSMMU . The ARCHITECT $25(\mathrm{OH})$ vitamin $\mathrm{D}$ assay was a chemiluminescent microparticle immunoassay for the quantitative determination of $25(\mathrm{OH})$ vitamin $\mathrm{D}$ in human serum and plasma. Statistical analysis of the data was done by Statistical Package for Social Science (SPSS) version 22.0. Confidence interval was considered at 95\% level. The qualitative variables were expressed as frequency and percentage and the quantitative variables were expressed 
as mean with standard deviation. During analysis, student's t-test and chi-square test were used to analyze difference between baseline characteristics. Univariate and multivariate regression analysis were considered to evaluate the influence of potential risk factors. Risk measurement was done by odds ratio (OR). P-value $<0.05$ was considered statistically significant in all cases.25 $(\mathrm{OH})$ vitamin D status was determined as the normal, insufficiency, deficiency and severely deficient state when the $25(\mathrm{OH})$ vitamin D level was $\leq 30 \mathrm{ng} / \mathrm{ml}$, $21-29 \mathrm{ng} / \mathrm{ml}, 10-20 \mathrm{ng} / \mathrm{ml}$ and $<10 \mathrm{ng} / \mathrm{ml}$ respectively. Multiple conditional logistic regression was used to investigate the relationship between $\mathrm{Ml}$ and vitamin $\mathrm{D}$ deficiency controlling for other significant traditional risk factors including diabetes, hypertension, dyslipidaemia, tobacco use, obesity/overweight and family h/opremature CAD. Vitamin D status was taken as a binaryvariable (moderate/severe deficiency Vs normal/insufficient).

\section{Results:}

Study subjects were divided into two main categories depending on whether the patient had vitamin $\mathrm{D}$ level $\leq$ $20 \mathrm{ng} / \mathrm{ml}$ (moderate/severe deficiency)or $>20 \mathrm{ng} / \mathrm{ml}$ (normal/insufficiency) in blood. Vitamin D status among cases and controls and the association of different grade of serum vitamin D with AMI was studied.

Mean age of cases and controls were $35.31 \pm 4.84$ years
$33.83 \pm 5.11$ years respectively $(P>.05)$. There was no statistically significant difference $(P>0.05)$ regarding the gender incidence in chi-square test. Male female ratio was 2.08:1 among the whole subjects.

In this study majority of both cases $(86.7 \%)$ and controls $(46.7 \%)$ had vitamin D deficiency (moderate) (Table II). Twenty percent $(20 \%)$ of cases had severe deficit in vitamin D level whereas none of the control group had severe deficit of vitamin $\mathrm{D}$. On the other hand, $10 \%$ of the controls had normal vitamin D level and none of the cases had normal level of vitamin D. In case group, the mean serum vitamin D level was $14.75 \pm 4.99 \mathrm{ng} / \mathrm{ml}$, ranging from 6.00 to $26.30 \mathrm{ng} / \mathrm{ml}$. In control group, the mean serum vitamin $D$ level was $21.05 \pm 6.00 \mathrm{ng} / \mathrm{ml}$, ranging from 11.00 $-31.00 \mathrm{ng} / \mathrm{ml}$. The difference was statistically significant $(P<0.001)$ (Table-l). Vitamin D deficient (moderate/severe) subjects were more likely to develop AMI than subjects who had normal/insufficient vitamin $D$ levels in blood (OR 7.42, 95\% Cl 3.18-18.28, $\mathrm{P}<0.001$ ). (Table III)

Smoking, HTN, F/H of premature CAD and vitamin D deficiency (moderate/severe) were found to be significantly $(p<0.05)$ associated with AMI in young $(\leq 40$ years) patients; other risk factors (DM, Dyslipidaemia and overweight/obese) were not found to be significantly $(p>0.05)$ associated with AMI risk in young ( $\leq 40$ years) patients. A subject with vitamin $D$ deficiency (moderate/ severe) compared to a not deficient subject (normal/ insufficient) was 8.81 (95\% Cl 2.874 to 27.023$)$ times

Table I

Comparison of serum 25(OH) Vitamin D level in cases and controls $(n=120)$.

\begin{tabular}{|c|c|c|c|c|c|}
\hline \multirow{2}{*}{$\begin{array}{l}\text { Serum 25-(OH) Vitamin D } \\
\text { level }(\mathrm{ng} / \mathrm{ml})\end{array}$} & \multicolumn{2}{|c|}{ Case $(n=60)$} & \multicolumn{2}{|c|}{ Control $(n=60)$} & \multirow[t]{2}{*}{$P$ value } \\
\hline & $\mathrm{n}$ & $\%$ & $\mathrm{n}$ & $\%$ & \\
\hline Normal $(\geq 30)$ & 0 & 0 & 6 & 10 & $0.01^{\mathrm{s}}$ \\
\hline Insufficient (21 - 29) & 8 & 13.3 & 26 & 43.3 & $<0.001^{\mathrm{s}}$ \\
\hline Moderately deficient $(10-20)$ & 40 & 66.7 & 28 & 46.7 & $0.03^{s}$ \\
\hline Severely deficient $(<10)$ & 12 & 20 & 0 & 0 & $<0.001^{\mathrm{s}}$ \\
\hline Mean $\pm S D$ & \multicolumn{2}{|c|}{$14.75 \pm 4.99$} & \multicolumn{2}{|c|}{$21.05 \pm 6.00$} & $<0.001^{\mathrm{s}}$ \\
\hline Range (min - max) & \multicolumn{2}{|c|}{$6.00-26.30$} & \multicolumn{2}{|c|}{$11.00-31.00$} & \\
\hline
\end{tabular}

Table-II

Vitamin D status (normal/insufficiency vs moderate/severe deficiency) among cases and controls $(n=120)$.

\begin{tabular}{|c|c|c|c|c|c|}
\hline \multirow[t]{2}{*}{ Serum 25-(OH) Vitamin-D Status } & \multicolumn{2}{|c|}{ Case $(n=60)$} & \multicolumn{2}{|c|}{ Control $(n=60)$} & \multirow[t]{2}{*}{$P$ value } \\
\hline & $\mathrm{n}$ & $\%$ & $\mathrm{n}$ & $\%$ & \\
\hline Deficient (moderate/severe) & 52 & 86.7 & 28 & 46.7 & $<0.001^{\mathrm{S}}$ \\
\hline Normal/ Insufficient & 8 & 13.3 & 32 & 53.3 & \\
\hline
\end{tabular}


Table-III

Risk measurement of serum $25(\mathrm{OH})$ vitamin $D$ level for $A M I$ in young ( $\leq 40$ years) patients $(n=120)$

\begin{tabular}{|c|c|c|c|c|c|c|c|}
\hline \multirow{2}{*}{$\begin{array}{l}\text { Serum } 25-(\mathrm{OH}) \\
\text { Vitamin-D Status }\end{array}$} & \multicolumn{2}{|c|}{$\begin{array}{l}\text { Case } \\
(n=60)\end{array}$} & \multicolumn{2}{|c|}{$\begin{array}{l}\text { Control } \\
(n=60)\end{array}$} & \multirow[t]{2}{*}{$\begin{array}{c}\text { Odds } \\
\text { Ratio (OR) }\end{array}$} & \multirow[t]{2}{*}{$\begin{array}{l}95 \% \mathrm{Cl} \\
\text { for OR }\end{array}$} & \multirow[t]{2}{*}{$P$ value } \\
\hline & $\mathrm{n}$ & $\%$ & $\mathrm{n}$ & $\%$ & & & \\
\hline $\begin{array}{l}\text { Deficient } \\
\text { (moderate/severe) }\end{array}$ & 52 & 86.7 & 28 & 46.7 & 7.42 & $3.18-18.28$ & $<0.001^{\mathrm{s}}$ \\
\hline Normal/ Insufficient & 8 & 13.3 & 32 & 53.3 & & & \\
\hline
\end{tabular}

Table-IV

Risk measurement of different risk factors for $A M I$ in young ( $\leq 40$ years) patients $(n=120)$ (Multiple logistic regression model)

\begin{tabular}{lcccc}
\hline Risk factors & $\begin{array}{c}\text { Regression } \\
\text { coefficient }(\beta)\end{array}$ & $\begin{array}{c}\text { Odds Ratio } \\
(\mathrm{OR})\end{array}$ & $95 \% \mathrm{Cl}$ for OR & $\mathrm{P}$ value \\
\hline Vitamin D deficiency(moderate/severe) & 2.176 & 8.81 & $2.874-27.023$ & $<0.001^{\mathrm{S}}$ \\
Smoking & 1.013 & 2.76 & $1.030-7.364$ & $0.04^{\mathrm{S}}$ \\
Dyslipidemia & 0.782 & 2.19 & $0.791-6.040$ & $0.13^{\mathrm{NS}}$ \\
HTN & 1.762 & 5.82 & $1.681-20.161$ & $0.005^{\mathrm{S}}$ \\
DM & 1.268 & 3.55 & $0.974-12.969$ & $0.06^{\mathrm{NS}}$ \\
F/H of premature CAD & 1.711 & 5.53 & $1.225-25.009$ & $0.02^{\mathrm{S}}$ \\
Overweight/Obese & 0.818 & 2.27 & $0.865-5.932$ & $0.10^{\mathrm{NS}}$ \\
\hline
\end{tabular}

more likely to have AMI.

\section{Discussion:}

This study was intended to find out the association between serum vitamin $\mathrm{D}$ level and $\mathrm{AMI}$ in young $(\leq 40$ years) patients.

Among cases $86.7 \%$ were deficient (moderate/severe) in vitamin $\mathrm{D}$ which is significantly more compared to controls (46.7\%, $\mathrm{P}<0.001)$. Among control group only $10 \%$ subjects had normal vitamin $D$ level. But, among cases there was not a single patient who had normal level of vitamin D. Till date no study has determined the vitamin $D$ status in both young ( $\leq 40$ years) adult men and women of Bangladesh. In this respect a high proportion of vitamin $\mathrm{D}$ deficient (moderate/severe) men (controls) in this study is a unique and important finding. A greater proportion of men among cases having hypovitaminosis $D$ can be explained by the fact that a greater proportion of men being hospitalized for myocardial infarction than women. ${ }^{17}$

Several studies were carried out to determine the vitamin $D$ level in adult women in the country,in one study vitamin $\mathrm{D}$ deficiency was found in $38 \%$ women and in another study vitamin $D$ deficiency $(<25 \mathrm{nmol} / \mathrm{l})$ was found in $16 \%$ female garments workers and a high prevalence of vitamin D insufficiency $88.5 \%$ was also noted.${ }^{18-19}$ In this study $30 \%$ women had vitamin $\mathrm{D}$ deficiency.

In 2017, at Sylhet MAG Osmani Medical College a study was done regarding association of 25hydroxycholecalciferol with acute myocardial infarction. In that studyvitamin D was found to be significantly reduced in AMI patients when compared with that of controls which were $28.50 \pm 16.68 \mathrm{ng} / \mathrm{ml}$ in cases and $38.32 \pm 16.47 \mathrm{ng} / \mathrm{ml}$ in controls, $\mathrm{P}=0.011 .20$

In an Indian study, Karur and colleagues included AMI patient from all ages and found $83.5 \%$ vitamin D deficiency or insufficiency.$^{21}$ In our study we found that all $(100 \%)$ patients of young ( $\leq 40$ years) AMI patients had either insufficient vitamin-D level $(13.3 \%)$ or moderate/ severely deficient vitamin-D level $(86.7 \%)$. In the study by Roy et al. severe deficiency of vitamin $D$ was found in $79.2 \%$ cases and $46.7 \%$ controls. $^{8}$ But, this study found severe deficiency in $20 \%$ cases and none of the control.

$\mathrm{Ng}$ et al., $2013^{22}$ demonstrated that $74 \%$ of AMI had low vitamin D levels and $36 \%$ of them had severe deficiency. In this study $86.7 \%$ of AMI had vitamin D deficiency (moderate/severe deficiency) level and among them 20\% had severe deficiency.

In this study serum $25(\mathrm{OH})$ vitamin D level in AMI was found to low in cases $(14.75 \pm 4.99 \mathrm{ng} / \mathrm{ml})$ than in controls $(21.05 \pm 6 \mathrm{ng} / \mathrm{ml})$ This findings were supported by the 
findings of Rath et al., $2016 .^{23}$

Risk measurement of serum $25(\mathrm{OH})$ vitamin $\mathrm{D}$ level for AMI showed that vitamin D deficient (moderate/severe) patients had significantly higher odds of developing AMI than those who have insufficient/normal vitamin $D$ level OR 7.42, 95\% Cl 3.18-18.28, $\mathrm{P}<0.001)$. When other risk factors were adjusted the OR increased to $8.81(95 \% \mathrm{Cl}$ 2.874- 27.023, $p<0.001)$. This in agreement with findings of studies done in India, Pakistan, and USA .8,24-25

In the multiple logistic regression analysis by taking AMI as dependent variable and risk factors for AMI as independent variable Roy et al., 20158, showed that vitamin D deficiency increased risk of AMI. In that study, vitamin D deficiency, obesity, DM, HTN, smoking and dyslipidaemia had odds ratio (OR) 4.5, 2.8, 2.3, 2.1, 1.9 and 1.1 respectively. In this study showed that serum vitamin D deficiency (moderate/severe), smoking, HTN and $\mathrm{F} / \mathrm{H}$ of premature CAD were significantly $(\mathrm{P}<0.05)$ associated with AMI risk in young (d"40years) patients with Odds ratio $8.81,2.76,5.83$ and 5.53 respectively. Whereas DM, Dyslipidaemia and overweight/obesity were not $(P>0.05)$ (Table IV).

Vitamin D deficiency (moderate/severe) causes an increase in parathyroid hormone, which increases insulin resistance and is associated with diabetes, hypertension, and inflammation .2 Combination of these factors contributes to the increased risk of cardiovascular events in vitamin D deficiency(moderate/severe). Therefore, large scale studies are needed to evaluate the cardiovascular benefits of vitamin D supplementation.

\section{Conclusion:}

Substantial evidence suggests that a large portion of different populations have suboptimal levels of vitamin $\mathrm{D}$, which may adversely affect the cardiovascular (CV) system, and may affect the incidence of AMI. Vitamin D deficiency (moderate/severe) was significantly associated with acute $\mathrm{MI}$ incidence.

\section{Limitations :}

The study population was confined to the Cardiology Department of DMCH. Therefore, the results of the study may not reflect the exact picture of the country. Only one of the emerging risk factors (serum vitamin D) was studied. Follow up of the patients for longer duration was beyond scope

\section{References:}

1. Grainger, D.J. and Mosedale, D.E. Metabolism in coronary heart disease. Heart Metabo; 2012;55:8-12.
2. Lee, J.H., O'Keefe, J.H., Bell, D., Hensrud, D.D. and Holic, M.F. Vitamin D deficiency: an important, common, and easily treatable cardiovascular risk factor?. JACC, 2008:52(24):1949-1956.

3. Holick, M. F., Binkley, N. C., Bischoff-Ferrari, H. A., Gordon, C. M., Hanley, D. A., Heaney, R. P., et al. Evaluation, treatment, and prevention of vitamin D deficiency: An endocrine society clinical practice guideline', Journal of Clinical Endocrinology and Metabolism; 2011;96(7): 1911-1930.

4. Zadshir, A., Tareen, N., Pan, D., Norris, K., and Martins, D. 2005. Ethnicity \& Disease, The prevalence of hypovitaminosis $\mathrm{d}$ among us adults. NHANES III; Volume 15.

5. Arabi, A., Rassi, R.E. and Fuleihan, G.E. 2011. Calcium Metabolism and Osteoporosis Program, Division of Endocrinology, Department of Internal Medicine, American University of Beirut, Review of vitamin $\mathrm{D}$ deficiency in developing countries. PO Box 11-0236, Riad Al Solh 1107, 2020,

6. Iyadurai, R., Sundararajan, S., Selayan, K., Govindaraj, R., Thenrajan, B., Sivaramalingam, G., et al. Vitamin D deficiency in acute coronary syndrome: a study in Govt. Royapettah Hospital. JEMDS, 2016:5(55), 3722-3726.

7. Hasan, S.M., Khan, H.L.R., Chowdhury, A.W., Sabah, K.M.N. and Ekram M.R. Prevalence and Pattern of Cardiac Emergencies In a Tertiary Care Hospital of Bangladesh. Bangladesh Critical Care Journal, 2013;1(1):23-26.

8. Roy, A., Ramakrishnan L., Tarik M., Tandon N., Srinath K.R. and Prabhakaran, D. Independent association of severe vitamin $\mathrm{D}$ deficiency as a risk of acute myocardial infarction in Indians. Indian Heart Journal 2015;67:27-32

9. Weishaar R.E. and Simpson R.U. Vitamin D3 and cardiovascular function in rats. J Clin Invest; 1987;79:1706-1712.

10. Weishaar, R.E., Kim, S.N., Saunders, D.E. and Simpson, R.U. 1990. Involvement of vitamin D3 with cardiovascular function. III. Effects on physical and morphological properties. American Journal of Physiology;258:E134-E142.

11. Holick, M.F. 2006, March. High prevalence of vitamin D inadequacy and implications for health. In Mayo Clinic Proceedings (Vol. 81, No. 3, pp. 353-373). 
12. Guessous, I., Bochud, M., Bonny, O. and Burnier, M. Calcium, vitamin D and cardiovascular disease. Kidney and Blood Pressure Research, 2011;34(6):404-417.

13. Shapses S.A. and Manson J. Vitamin D and Prevention of Cardiovascular Disease and Diabetes: Why the Evidence Falls Short. JAMA; 2011;305:2565-2566.

14. Wang, T.J., Pencina, M.J., Booth, S.L., Jacques, P.F., Ingelsson, E., Lanier, K., et al. Vitamin D deficiency and risk of cardiovascular disease. Circulation, 2008;117(4):503-511.

15. Dobnig, H., Pilz, S., Scharnagl H., Renner W., Seelhorst U., Wellnitz B., et al. Independent association of low serum 25-hydroxyvitamin $D$ and 1, 25-dihydroxyvitamin $\mathrm{D}$ levels with all-cause and cardiovascular mortality. Archives of internal medicine, 2008;168(12):1340-1349.

16. Brøndum-Jacobsen, P., Benn, M., Jensen, G.B. and Nordestgaar, B.G. 25-hydroxyvitamin d levels and risk of ischemic heart disease, myocardial infarction, and early death: population-based study and meta-analyses of 18 and 17 studies. Arteriosclerosis, thrombosis, and vascular biology, 2012;32(11):2794-2802.

17. Gupta, A., Wang, Y., Spertus, J.A., Ged, M., Lorenze, N., Nkonde-Price, C., et al. Trends in acute myocardial infarction in young patients and differences by sex and race, 2001 to 2010. JAMA, 2014;64(4):337-345.

18. Islam, M. Z., Lamberg-Allardt, C., Kärkkäinen, M., Outila, T., Salamatullah, Q. and Shamim A. A. Vitamin D deficiency: A concern in premenopausal Bangladeshi women of two socio-economic groups in rural and urban region. European Journal of Clinical Nutrition; 2002;56(1): 51-56.

19. Islam, M. Z., Shamim, A. A., Kemi, V., Nevanlinna, A., Akhtaruzzaman, M., Laaksonen, M., et al. Vitamin D deficiency and low bone status in adult female garment factory workers in Bangladesh. British Journal of Nutrition; 2008;99(6):1322-1329.

20. Islam, M.E., Majumder, M., Debnath, B.C., Serajuddin, K. and Hossain, M.S. Association of 25-OH Cholecalciferol with Acute Myocardial Infarction. Bangladesh Journal of Medical Biochemistry, 2017;8(2):55-59.

21. Karur, S., Veerppa, V. and Najappa, M.C. Study of vitamin $D$ deficiency prevalence in acute myocardial infarction. Indian Journal of Cardiology Heart and vessels 2014;3:57-59.

22. Ng, L.L., Sandhu, J.K., Squire, I.B., Davies, J.E. and Jones DJ. Vitamin D and prognosis in acute myocardial infarction. International journal of cardiology, 2013;168(3):2341-2346.

23. Rath D, Nanda R., Mishra P. K. and Patra P. K. Evaluation of Serum 25 Hydroxy Vitamin D level in acute myocardial infarction patients in a tertiary care hospital. Asian Journal of Medical Sciences, 2016;7(6):11.

24. Iqbal, M. P., Mehboobali, N., Azam, I. and Tareen, A. K. 'Association of alkaline phosphatase with acute myocardial infarction in a population with high prevalence of hypovitaminosis D. Clinica Chimica Acta. Elsevier B.V. 2013; 425:192-195.

25. Giovannucci, E., Liu, Y., Hollis, B.W. and Rimm E.B. 25-hydroxyvitamin $D$ and risk of myocardial infarction in men: a prospective study. Archives of internal medicine, 2008; 168(11): 1174-1180. 